\title{
Long-term Surgical Results of the Lumbar Spinal Stenosis
}

\author{
Ki-Jeong Kim ${ }^{\bowtie}$, Seung-Jae Hyun, Tae-Ahn Jahng, Hyun-Jib Kim \\ Department of Neurosurgery, Spine Center, Seoul National University Bundang Hospital, Seoul National University College of \\ Medicine, Seongnam, Korea
}

$\triangle$ Corresponding Author: Ki-Jeong Kim, Department of Neurosurgery, Spine Center, Seoul National University Bundang Hospital, Seoul National University College of Medicine, 82, Gumi-ro 173 Beon-gil, Bundang-gu, Seongnam 13620, Korea. Tel: +82-31-787-7169, Fax: +82-31-787-4097, E-mail: kijeong@snu.ac.kr

\section{INTRODUCTION}

Lumbar spinal stenosis is one of the most common degenerative spinal disorders in adult population especially over sixth decade ${ }^{9}$. As degenerative changes in the spine are progressive with increasing age of the patients, the elderly patients with lumbar spinal stenosis usually suffer more severe symptoms and disabilities than younger adults. In recent days, as the proportion of elderly population is increasing in developed countries as well as in Korea, patients having severe symptomatic lumbar spinal stenosis are increasing and these patients often fail in conservative treatments ${ }^{39,43)}$.

The Degenerative Lumbar Spinal Stenosis Work Group of the North American Spine Society's (NASS) Evidence-Based Clinical Guideline Development Committee has developed an evidence-based clinical guideline on diagnosis and treatment of degenerative lumbar spinal stenosis in 2008 and its update in 2013. They recommended that decompressive surgery is suggested to improve outcomes in patients with moderate to severe symptoms of lumbar spinal stenosis with grade of recommendation $\mathrm{B}$ and medical or interventional treatment may be considered for patients with moderate symptoms of lumbar spinal stenosis with grade of recommendation $\mathrm{C}^{42,58)}$. However, reported long term successful clinical outcomes of lumbar spinal stenosis have wide range of variation from $26 \%$ to $100 \% \%^{1,2,9,14,19,26,32,35,36,57,62)}$. Therefore, it seems to be obvious a patient with severe symptomatic lumbar spinal stenosis can be benefited with surgical treatment. Nonetheless it is still difficult to expect how an individual patient will be benefited with surgery preoperatively.

In this review article, long term surgical results of the patients with lumbar spinal stenosis, associated prognostic factors, and other topics will be discussed based on literature review.

\section{BENEFITS OF THE SURGICAL TREATMENTS}

Several prospective studies have been conducted to elucidate the benefits of the surgical treatments for lumbar spinal stenosis over conservative treatment (Table 1). In 1991, Johnsson et al. followed up 44 patients of surgical group for 53 months and 19 patients of untreated group for 31 months ${ }^{33)}$. They reported one third of the surgical and one half of the untreated patients still had neurogenic claudication. By visual analogue scale estimation, $60 \%$ of those treated surgically and $33 \%$ of the untreated patients felt better and $58 \%$ of the untreated patients were unchanged. They concluded that since severe deterioration was not found in the untreated patients, observation for 2-3 years seems to be a good alternative to surgery. Amundsen et al. published average 10 year follow up data from prospective study of 32 surgical patients and 68 conservative patients ${ }^{2}$. According to their result, excellent or fair results were found in a half of the patients selected for conservative treatment and in four fifths of the patients selected for surgery during the first 4 years and significant deterioration of symptoms was not observed in the period of following 4 to 10 years. They concluded that treatment result for the patients randomized for surgical treatment was considerably better than those randomized for conservative treatment. In 1996, the first one year result of a community based prospective cohort study, the Maine Lumbar Spine Study (MLSS), comparing the outcome of surgical and non-surgical treatment for lumbar spinal stenosis was reported ${ }^{7}$. The one year result of MLSS indicated 55\% of surgical and $28 \%$ of non-surgical patients reported definite improvement in their predominant symptoms $(p=0.003)$. Surgical treatment remained a significant determinant of 1-year outcome, even after adjustment for differences between treatment groups 
Table 1. The results of the comparative studies of surgery versus conservative management for lumbar spinal stenosis

\begin{tabular}{|c|c|c|c|c|c|}
\hline $\begin{array}{l}\text { Authors } \\
\text { (Year) }\end{array}$ & Study design & $\begin{array}{l}\text { Surgical Non-surgical } \\
\text { patients patients }\end{array}$ & $\mathrm{FU}^{\dagger}$ & Results & Conclusion \\
\hline
\end{tabular}

Johnsson

et al. (1991)

44

19

53 vs. 31

the surgical and $1 / 2$ of the conservative patients still had neurogenic claudication. By visual found in the untreated patients, a analogue-scale estimation, $60 \%$ of those treated observation for 2-3 years seems to be surgically and $33 \%$ of the untreated patients felt better. a good alternative to surgery.

\begin{tabular}{|c|c|c|c|c|c|c|}
\hline $\begin{array}{l}\text { Atlas et al. } \\
\text { (1996) }\end{array}$ & $\begin{array}{l}\text { Prospective } \\
\text { observational } \\
\text { cohort }\end{array}$ & 81 & 67 & 1 & $\begin{array}{l}28 \% \text { of non-surgically and } 55 \% \text { of surgically treated } \\
\text { patients reported definite improvement in their } \\
\text { predominant symptoms }(p=0.003) \text {. Surgical } \\
\text { treatment remained a significant determinant of } \\
\text { 1-year outcome, even after adjustment for other } \\
\text { independent predictors }(p=0.05) \text {. }\end{array}$ & $\begin{array}{l}\text { Patients with severe lumbar spinal } \\
\text { stenosis who were treated surgically } \\
\text { had greater improvement than those } \\
\text { treated non-surgically. }\end{array}$ \\
\hline
\end{tabular}

Amundsen Prospective et al. (2000)

$32 \quad 68$

10

\section{$10 \quad$ Afte} were found in half of the patients selected for conservative treatment, and in four fifths of the
cound in half of the patients selected for conservative treatment, and in four fifths of the was considerably better than for the
patients selected for surgery. Clinically significant patients randomized for conservative deterioration of symptoms during the final 6
of the follow-up period was not observed.

\begin{tabular}{|c|c|c|c|c|c|}
\hline $\begin{array}{l}\text { Atlas et al. } \\
(2000)\end{array}$ & $\begin{array}{l}\text { Prospective } \\
\text { observational } \\
\text { cohort }\end{array}$ & 80 & 68 & 4 & $\begin{array}{l}70 \% \text { of the surgically treated and } 52 \% \text { of the non- For the patients with severe lumbar } \\
\text { surgically treated patients reported that their predo- spinal stenosis, surgical treatment was } \\
\text { minant symptom (either leg or back pain) was better associated with greater improvement } \\
(p=0.05) \text {. Satisfaction of patients with their current in patient-reported outcomes than } \\
\text { state at } 4 \text { years was reported by } 63 \% \text { of the surgi- nonsurgical treatment at 4-year evalu- } \\
\text { cally treated and } 42 \% \text { of the non-surgically treated ation. The relative benefit of surgery } \\
\text { patients }(p=0.04) \text {. Surgical treatment remained a signifi- declined over time but remained } \\
\text { cant determinant of } 4 \text {-year satisfaction, even after } \\
\text { adjustment for other independent predictors }(p=0.001) \text { superior to nonsurgical treatment. }\end{array}$ \\
\hline $\begin{array}{l}\text { Atlas et al. } \\
(2000)\end{array}$ & $\begin{array}{l}\text { Prospective } \\
\text { observational } \\
\text { cohort }\end{array}$ & 56 & 41 & 8 to 10 & 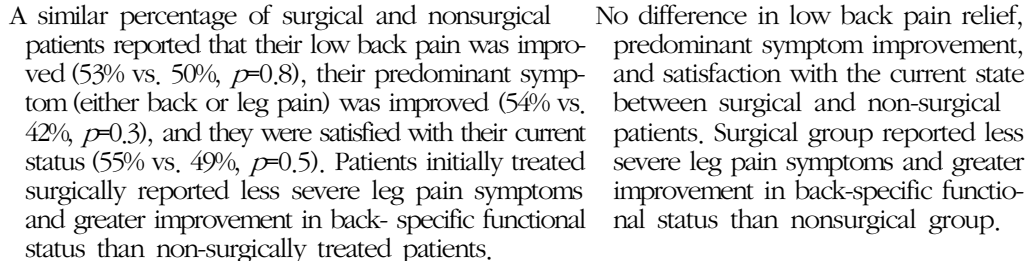 \\
\hline
\end{tabular}

\begin{tabular}{|c|c|c|c|c|c|c|}
\hline $\begin{array}{l}\text { Malmivaara } \\
\text { et al. (2007) }\end{array}$ & $\begin{array}{l}\text { Randomized } \\
\text { controlled }\end{array}$ & 50 & 44 & 2 & $\begin{array}{l}\text { At } 1 \text { year, the mean difference in favor of surgery } \\
\text { was } 11.3 \text { in disability (CI, 4.3-18.4), } 1.7 \text { in leg pain } \\
\text { (CI, 0.4-3.0), and } 2.3 \text { (CI, 1.1-3.6) in back pain. At } \\
\text { the 2-year follow-up, the mean differences were } \\
\text { slightly less: } 7.8 \text { in disability }(95 \% \mathrm{CI}, 0.8-14.9) 1.5 \\
\text { in leg pain }(95 \% \mathrm{CI}, 0.3-2.8) \text {, and } 2.1 \text { in back pain } \\
(95 \% \mathrm{CI}, 1.0-3.3) \text {. Walking ability, either reported } \\
\text { or measured, did not differ between the two } \\
\text { groups. }\end{array}$ & $\begin{array}{l}\text { Although patients improved over the } \\
\text { 2-year follow-up regardless of initial } \\
\text { treatment, those undergoing decom- } \\
\text { pressive surgery reported greater im- } \\
\text { provement regarding leg pain, back } \\
\text { pain, and overall disability. The relative } \\
\text { benefit of initial surgical treatment di- } \\
\text { minished over time, but outcomes of } \\
\text { surgery remained favorable at } 2 \text { years. }\end{array}$ \\
\hline $\begin{array}{l}\text { Athiviraham } \\
\text { et al. (2007) }\end{array}$ & $\begin{array}{l}\text { Prospective, } \\
\text { non-randomized }\end{array}$ & 96 & 29 & 2 & $\begin{array}{l}\text { Of the patients, } 54 \text { underwent decompression only, } \\
42 \text { decompression and fusion, and } 29 \text { declined } \\
\text { surgery. At } 2 \text { years, the average improvements in } \\
\text { RMQ were } 6.9,6.1 \text {, and } 1.2 \text {, respectively. Percentages } \\
\text { of better than before surgery were } 63.3 \%, 61.5 \% \text {, } \\
\text { and } 25.0 \% \text {, respectively. }\end{array}$ & $\begin{array}{l}\text { A majority of patients declining surgery } \\
\text { had persistent symptoms. The } \\
\text { majority of patients who choose } \\
\text { surgery will be improved but will } \\
\text { have residual symptoms }\end{array}$ \\
\hline $\begin{array}{l}\text { Weinstein } \\
\text { et al. (2008) }\end{array}$ & $\begin{array}{l}\text { Randomized trial } \\
\text { and concurrent } \\
\text { observational } \\
\text { cohort study }\end{array}$ & 394 & 240 & 2 & $\begin{array}{l}\text { A significant treatment effect favoring surgery on the } \\
\text { SF-36 (BP) with a mean difference in change from } \\
\text { baseline of } 7.8(\mathrm{CI}, 1.5-14.1) ; \text { No significant } \\
\text { difference in scores on SF-36 (PF) or ODI }\end{array}$ & $\begin{array}{l}\text { A significant advantage for surgery by } \\
3 \text { months for all primary outcomes; } \\
\text { these changes remained significant at } \\
2 \text { years. }\end{array}$ \\
\hline $\begin{array}{l}\text { Weinstein } \\
\text { et al. }(2010)\end{array}$ & $\begin{array}{l}\text { Randomized } \\
\text { trial and } \\
\text { concurrent } \\
\text { observational } \\
\text { cohort study }\end{array}$ & 419 & 235 & 4 & $\begin{array}{l}\text { A significant treatment effects for the SF-36 (BP) } 12.6 \\
\text { (CI, 8.5-16.7); PF 8.6 (CI, 4.6-12.6); and ODI -9.4 } \\
\text { (CI, -12.6 to -6.2). Early advantages for surgical } \\
\text { treatment for secondary measures such as } \\
\text { bothersomeness, satisfaction with symptoms, and } \\
\text { self-rated progress were also maintained }\end{array}$ & $\begin{array}{l}\text { Patients with symptomatic spinal } \\
\text { stenosis treated surgically compared } \\
\text { to those treated nonoperatively } \\
\text { maintain substantially greater } \\
\text { improvement in pain and function } \\
\text { through } 4 \text { years. }\end{array}$ \\
\hline $\begin{array}{l}\text { Slätis et al. } \\
(2011)\end{array}$ & Randomized & 50 & 45 & 6 & $\begin{array}{l}\text { The mean difference in ODI in favour of surgery was } \\
9.5(p=0.006) \text {, whereas the intensity of leg or back } \\
\text { pain did not differ between the two treatment } \\
\text { groups any longer. Walking ability did not differ } \\
\text { between the treatment groups at any time. }\end{array}$ & $\begin{array}{l}\text { Decompressive surgery provided } \\
\text { modest but consistent improvement } \\
\text { in functional ability, surpassing that } \\
\text { obtained after non-operative measures. }\end{array}$ \\
\hline
\end{tabular}

Abbreviations: CI: 95\% confidence interval, RMQ: Rolland-Morris questionnaire, ODI: Oswestry disability index, SF-36: 36-item Short-Form General Health Survey, BP: Bodily pain, PF: physical function

${ }^{\dagger}$ FU: Follow up duration in years (except a study by Johnnson et al.) 
at entry $(p=0.05)^{6}$. Four years later, the MLSS resulted that $70 \%$ of the surgically treated and $52 \%$ of the non-surgically treated patients reported that their predominant symptom, either leg or back pain, was better $(p=0.05)$. Satisfaction of patients with their current state at 4 years was reported by $63 \%$ of the surgically treated and $42 \%$ of the non-surgically treated patients $(p=0.04)$. Surgical treatment remained a significant determinant of 4-year satisfaction, even after adjustment for other independent predictors $(p=0.001)^{8}$. They also found the relative benefit of surgery declined over time but remained superior to nonsurgical treatment in four year follow up study. Declining relative benefit of surgical treatment was more evident in their longer follow up data8. Among total 148 eligible patients, 105 patients were survived until their 8 to 10 -year follow up and there were 56 surgical and 41 non-surgical patients. Their latest result demonstrated no significant difference in low back pain relief, predominant symptom improvement, and satisfaction with the current state between the two treatment groups. Nevertheless, surgical group reported less severe leg pain symptoms and greater improvement in back-specific functional status after 8 to 10 years than nonsurgical group ${ }^{9}$. In conclusion, the MLSS result supported that the relative benefit favoring surgical treatment although most of the improvement in outcome due to surgery was seen shortly after patients' entry into the study followed by a narrowing of the relative benefit of surgical treatment. Another prospective non-randomized study was conducted by Athiviraham et al. ${ }^{5}$. There were 125 patients in total and 54 underwent decompression only, 42 had decompression and fusion for preexisting spondylolisthesis, and 29 patients declined surgery. At 2 years follow-up, the average improvements in Roland-Morris questionnaire score in the decompression only, decompression with fusion, and nonsurgical groups were $6.9,6.1$, and 1.2, respectively. The percentages of patients who were better, worse, or the same were similar for those who had decompression only $(63.3 \%$, $4.1 \%$, and $32.7 \%$, respectively) and decompression with fusion (61.5\%, 2.6\%, and $35.9 \%$, respectively) but different from those treated without surgery $(25.0 \%, 12.5 \%$, and $62.5 \%$, respectively). While a majority of patients declining surgery had persistent symptoms, the majority of patients who choose surgery will be improved but will have residual symptoms.

Malmivaara et al. conducted a randomized controlled study based on four university hospitals of Finland ${ }^{44)}$. There were 50 surgical and 44 non-operative patients and follow up period was 2 years. Their result showed improvement of clinical outcome in both treatment groups during follow-up and walking ability, either reported or measured, did not differ between the two treatment groups. However, at 1 year, the mean difference in favor of surgery was 11.3 in disability ( $95 \%$ confidence interval [CI], 4.3-18.4), 1.7 in leg pain (95\% CI, 0.4-3.0), and 2.3 (95\% CI, 1.1-3.6) in back pain. At the 2-year follow-up, the mean differences were slightly decreased; 7.8 in disability $(95 \%$ CI,
0.8-14.9) 1.5 in leg pain (95\% CI, 0.3-2.8), and 2.1 in back pain (95\% CI, 1.0-3.3). They concluded those undergoing decompressive surgery reported greater improvement regarding leg pain, back pain, and overall disability at least 2 years follow up. They also indicated that the relative benefit of initial surgical treatment diminished over time in accordance with the result of the MLSS. The Spine Patient Outcomes Research Trial (SPORT) was an investigator-initiated study conducted in 11 states at 13 U.S. medical centers with multidisciplinary spine practices ${ }^{59,60)}$. The study included both a randomized cohort and a concurrent observational cohort of patients who declined to undergo randomization. A total of 289 patients were enrolled in the randomized cohort, and 365 patients were enrolled in the observational cohort. At 2 years, $67 \%$ of patients who were randomly assigned to surgery had undergone surgery, whereas $43 \%$ of those who were randomly assigned to receive nonsurgical care had also undergone surgery, that was, 394 patients in surgical group and 240 in nonsurgical group. The intention-totreat analysis of the randomized cohort showed a significant treatment effect favoring surgery on the 36-item Short-Form General Health Survey (SF-36) scale for bodily pain (BP), with a mean difference in change from baseline of $7.8(95 \% \mathrm{CI}$, 1.5-14.1). However, there was no significant difference in scores on physical function (PF) or on the Oswestry Disability Index (ODI). The as-treated analysis (surgery versus nonsurgical treatment), which combined both cohorts and was adjusted for potential confounders, showed a significant advantage for surgery by 3 months for all primary outcomes; these changes remained significant at 2 years ${ }^{60)}$. In addition, their four years result of 419 surgical and 235 nonsurgical patients also indicated that patients with symptomatic spinal stenosis treated surgically compared to those treated non-operatively maintain substantially greater improvement in pain and function through 4 years ${ }^{59}$.

Another randomized trial was conducted to evaluate the long-term efficacy of operative treatment as compared with results obtained by non-operative measures in patients with 'moderate' lumbar spinal stenosis ${ }^{54)}$. There were 50 surgical and 45 non-operative patients and follow up period was 6 years. Their result showed that the mean difference in ODI in favor of surgery was $9.5(p=0.006)$, whereas the intensity of leg or back pain did not differ between the two treatment groups any longer. Walking ability did not differ between the treatment groups at any time. They concluded decompressive surgery of moderately symptomatic lumbar spine stenosis provided modest but consistent improvement in functional ability, surpassing that obtained after non-operative measures.

On the contrary, Cochrane review results indicated that there is no scientific evidence about the effectiveness of any form of surgical decompression or fusion for degenerative lumbar spondylosis compared with natural history, placebo, or conservative treatment ${ }^{23)}$. However, treatment paradigms are usually different in even a single disease entity according to various affecting 
Table 2. Long term (>4 years) surgical outcomes in retrospective studies for lumbar spinal stenosis

\begin{tabular}{|c|c|c|c|c|}
\hline Authors (Year) & $\mathrm{N}$ & $\mathrm{Age}^{\dagger}$ & $\mathrm{FU}$ & Result \\
\hline Caputy et al. (1992) & 100 & 67 & $>5$ & Success rate: $64 \%$ \\
\hline Herno et al. (1993) & 108 & 50.7 & 12.8 & Excellent to good outcome: $68 \%$ \\
\hline Tuite et al. (1994) & 119 & 61.8 & 4.6 & Much or somewhat improved: $66 \%$ \\
\hline Sanderson et al. (1996) & 57 & 56 & 8.4 & No leg pain: $72 \%$ \\
\hline Katz et al. (1996) & 88 & 69.3 & 8.1 & Satisfaction: $75 \%$ \\
\hline Airaksinen et al. (1997) & 438 & 52 & 4.3 & Excellent to good outcome in ODI: $62 \%$ \\
\hline Scholz et al. (1998) & 72 & 59.7 & $2.5+8$ & Good outcome: $73.6 \%$ (2.5 years), $62.1 \%$ (8 years later) \\
\hline Rompe et al. (1999) & 117 & 61 & 8 & $\begin{array}{l}\text { Excellent to good outcome: } 36 \% \text { (undercutting group), 30.8\% (laminectomy group), } \\
23.8 \% \text { (laminectomy and fusion group) }\end{array}$ \\
\hline Cornefjord et al. (2000) & 96 & 64.4 & 7.1 & $\begin{array}{l}65 \% \text { of the patients claimed a satisfactory result, improved leg pain, low back pain, } \\
\text { walking capacity }\end{array}$ \\
\hline Jolles et al. (2001) & 77 & 61 & 6.5 & Excellent or good outcome: $79 \%$ \\
\hline Hee et al. (2003) & 68 & 68 & 8 & Back pain relieved in $91 \%$, leg pain relieved in $76 \%$, numbness relieved in $87 \%$ \\
\hline Gelalis et al. (2006) & 50 & 59.9 & 11.6 & Excellent to good outcome: $72 \%$ \\
\hline Xia et al. (2008) & 49 & 67.2 & 6.3 & $\begin{array}{l}69.4 \% \text { of the patients were classified into the recovery groups, average recovery } \\
\text { rate (JOA) of } 48.1 \pm 36.8 \%\end{array}$ \\
\hline Bouras et al. (2010) & 182 & 71.2 & 5 & VAS improvement $84.8 \%$, ODI improvement in $69.6 \%, 81.6 \%$ were satisfied \\
\hline
\end{tabular}

factors. Likewise optimal treatments for lumbar spinal stenosis will be varied according to severity of symptoms or functional status of the patients. The results of above prospective observational or randomized studies comparing surgical and non-surgical treatment for lumbar spinal stenosis have supported sufficient evidence for us to accept benefit of surgical decompression with or without fusion at least severe symptomatic patients.

Amundsen et al. did not find long term deterioration of symptom during 5 to 10 years in their surgical group ${ }^{2)}$. But the MLSS and SPORT studies indicated benefit from decompressive surgery was slowly diminished during long term follow up $^{9,60)}$. As most of the lumbar spinal stenosis is caused by degenerative process of the spine, it may be natural phenomenon that symptoms of patients will be deteriorated during follow up and patients having decompressive surgery will not be exception. The effect or benefit of surgery will be limited within the decompressed segments of index surgery. Therefore, the role of surgery for lumbar spinal stenosis should be judged within the range of an index surgery though it is not easy to determine in reality. If a surgical patient has recurrent stenosis at the index level, the role of the surgery is to be questioned. However, it is not reasonable to regard clinical deterioration of a surgical patient's symptom and functional status as detrimental effect of index surgery only.

\section{LONG-TERM SURGICAL OUTCOMES}

In 1992, Turner et al. published a meta-analysis of surgical outcome of lumbar spinal stenosis. They analyzed 74 articles and indicated that $64 \%$ of patients undergone surgical treatment were reported to have good-to-excellent outcomes on average $^{57)}$. However, good-to-excellent outcome in the individual articles had wide range from $26 \%$ to $100 \%$. Based on each study population, there were significant differences in terms of numbers of patients enrolled, age, gender, severity and location of spinal stenosis, multiplicity of lesions, co-morbidity, methods of surgical treatment, follow up periods, and outcome assessment tools among the studies. Therefore, a direct comparison of the results in literature is very difficult and confusing. In addition, since many authors reported long term deterioration of surgical outcomes, relatively shorter term outcome reports may have some demerit in acceptance as generalized scientific data ${ }^{2,9,35,44,52,62)}$.

The overall successful outcomes of surgical treatments for lumbar spinal stenosis, based on retrospective studies with more than 4-year follow up, were $23.8-91 \%$ according to various

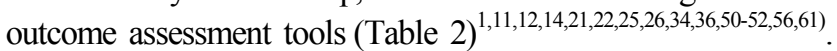
In 1997, Airaksinen et al. studied 438 patients with lumbar spinal stenosis and average 4.6-year follow up period after surgery and noted a good to excellent outcome in $62 \%$ of the patients ${ }^{1)}$. It was a single institute result of decompressive laminectomy without fusion and one of the largest study populations in literature. The same institute also reported average 12.8 years follow up result for decompressive laminectomy without fusion for 108 patients with lumbar spinal stenosis and good-to-excellent outcome was reported in $68 \%$ of the 
patients $^{26}$. More recent study with more than 10 years follow up was reported by Gelalis et al. There was a total of 50 patients, including 5 patients with fusion, had average follow-up period of 11.6 years and excellent to good outcomes were noted in $72 \%$ of the patients ${ }^{22}$. On the other hand, there were some studies reporting dismal outcomes. Rompe et al. conducted a retrospective study for 117 consecutive patients and reported good to excellent outcomes were noted in $36 \%$ of undercutting decompression group, $30.8 \%$ in laminectomy, and $23.8 \%$ in laminectomy with fusion after mean follow-up of 8 year (72 responders). Moreover, 25 of 72 patients (34.7\%) had severe constant back and/or leg pain requiring daily administration of analgesics $^{50)}$. Katz et al. also reported $33 \%$ of their 88 patients having severe back pain and $53 \%$ being unable to walk two blocks although $75 \%$ of the patients were satisfied with the results of surgery ${ }^{36}$.

The results of prospective studies of surgical treatment for lumbar spinal stenosis were ranged from $45.9 \%$ to $75.6 \%$ (Table $3)^{9,19,24,32,35,38,41,62)}$. In comparing with retrospective series, prospective studies tended to have less study populations and shorter follow up period. Javid et al. summarized the results of 8 prospective studies published from 1983 to 1997. There were a total of 983 patients and average follow up period was 2 years (range; $0.5-5$ years). The mean success rate was $67.8 \%$ (range; $52-78 \%)^{32)}$. Kleinstück et al. conducted a prospective study including 221 patients of degenerative lumbar spinal stenosis which was one of the largest study populations in literature. They used data of the Spine Society of Europe Spine Tango system and inclusion criteria were first-time surgery, maximum 3 affected levels, and decompression as the only procedure. According to their outcome measurement using the multidimensional Core Outcome Measures Index at 12 months, the patient-rated global outcomes were as followed: 94 of 221 (42.5\%) operation helped a lot; 73 of $221(33.0 \%)$ operation helped; 27 of $221(12.2 \%)$ operation helped only little; 22 of $221(10.0 \%)$ operation did not help; and 5 of $221(2.3 \%)$ operation made things worse. Hence, 167 of 221 (75.6\%) patients had a good outcome, and 54 of 221 (24.4\%) had a poor outcome $\mathrm{e}^{41)}$. A relatively short follow up period (average 12 months) of this study, however, was one of the limitations. A prospective study with longest follow up period was reported by Atlas et al. (MLSS). After 8 to 10 years follow up, 56 surgical patients reported improved low back pain in 52.8\% of the patients, improved leg pain in $66.7 \%$, satisfied with current status in $55.4 \%{ }^{9}$. . A lowest functional outcome among prospective studies of decompressive surgery for lumbar spinal stenosis was reported by Foulongne et al. They found favorable functional outcome in $45.9 \%$ of 98 patients with decompressive laminectomy including one patient with simultaneous internal fixation after 5-year follow up. Their functional outcome was measured by use of the Beaujon score. They indicated the Beaujon score allowed a more global perspective for patient and corresponded to a real improvement of the patient's functional status. However, considering that the study showed a significant improvement of the patients after surgery (Beaujon score: from $9.3 \pm 3.1$ preoperatively to $14.1 \pm 4.2$ at five year, $p=0.001$ ), a relatively low value of favorable functional outcome might be influenced partly by more strict criterion to assess outcome ${ }^{19)}$.

One of the most important issues in long term outcome of surgical treatment for lumbar spinal stenosis may be deterioration of clinical outcome with time. Amundsen et al. said that clinically significant deterioration of symptoms during the final 6 years of the follow-up period was not observed in 32 patients undergone decompressive laminectomy in 10-year follow up ${ }^{2}$. Jolles et al. also pointed that there was no deterioration in 77 patients (decompressive laminectomy in 65 and associated fusion in 12) during average 6.5-year follow-up. The results of the SPORT study also pointed that outcomes in surgical and non-operative groups were stable between 2 and 4 years ${ }^{59}$. Furthermore, Herno et al. reported the results of 108 patients

Table 3. Surgical outcomes in prospective studies of lumbar spinal stenosis

\begin{tabular}{|c|c|c|c|c|}
\hline Authors (Year) & $\mathrm{N}$ & $\operatorname{Age}^{\dagger}$ & FU & Result \\
\hline Grob et al. (1995) & 45 & 67 & 2.3 & Success rate: $73 \%$ \\
\hline Jönsson et al. (1997) & 105 & - & 5 & Excellent outcome: $52 \%$ \\
\hline Javid et al. (1998) & 170 & $53.6-64.7$ & 5.1 & $\begin{array}{l}\text { Success rate: } 70.8 \% \text { (lumbar stenosis), } 66.6 \% \text { (lumbar stenosis and } \\
\text { herniated disc), } 63.6 \% \text { (lateral stenosis) }\end{array}$ \\
\hline Katz et al. (1999) & 199 & 69 & 2 & $73 \%$ satisfied, $31 \%$ severe pain, $42 \%$ can walk more than 1 mile \\
\hline Atlas et al. (2005) & 56 & 65.7 & $8-10$ & $\begin{array}{l}\text { Low back pain improved in } 52.8 \% \text {, leg pain improved in } 66.7 \% \text {, } \\
\text { satisfied with current status in } 55.4 \%\end{array}$ \\
\hline Yamashita et al. (2006) & 70 & 65.9 & 5 & $\begin{array}{l}\text { VAS improvements were significant }(\mathrm{p}<0.0002 \text { for back pain, } \mathrm{p}<0.0001 \\
\text { for the other symptoms). }\end{array}$ \\
\hline Kleinstuck et al. (2009) & 221 & 72.4 & 1 & Good outcome: $75.6 \%$ \\
\hline Foulongne et al. (2013) & 98 & 67.3 & 5 & Favorable functional outcome (Beaujon score): $45.9 \%$ \\
\hline
\end{tabular}

Abbreviations: N: number of patients. FU: follow up period in years. VAS: visual analog scale.

${ }^{\dagger}$ Mean age in years 
improved during the course of the longitudinal follow-up time of 7 and 13 years $^{26}$. However, more number of studies supported progressive deterioration of benefit of surgical treatment during long term follow up period ${ }^{2,9,35,36,44,50,52,62)}$. In the MLSS of 8 to 10-year follow up result, the authors commented that most of the improvement in outcome due to surgery was seen shortly after patients' entry into the study followed by a narrowing of the relative benefit of surgical treatment. From years 2 through 10 , there was slight worsening of the frequency of symptoms and Roland functional status over time in both treatment groups and to a similar extent. There was a slight increase in satisfaction with the current state for non-surgically treated patients and a slight decrease for surgically treated patients between 2 and
10 years. In considering pathogenesis of degenerative lumbar spinal stenosis, it is more reasonable to regard symptoms of lumbar spinal stenosis to be progressive as time goes on and a decline of beneficial effect of surgical treatment may be observed during long term follow up. However, deterioration of surgical outcome during long term follow up should not underscore the role of decompressive surgery for symptomatic lumbar spinal stenosis because most of the studies have supported better global outcome in surgical patients than non-surgical patients.

\section{PROGNOSTIC FACTORS}

Prognostic factors related with surgical outcome of lumbar

Table 4. Clinical prognostic factors of surgical treatment for lumbar spinal stenosis

\begin{tabular}{|c|c|c|c|c|c|c|}
\hline Authors & Study design & $\mathrm{N}$ & FU & Favorable factors & Unfavorable factors & Factors not related with outcome \\
\hline $\begin{array}{l}\text { Tuite et al. } \\
\text { (1994) }\end{array}$ & Retrospective & 119 & 4.6 & & Need for additional surgery & $\begin{array}{l}\text { Age, gender, duration of } \\
\text { preoperative symptoms, worker's } \\
\text { compensation, character of the } \\
\text { presenting symptoms, extent of } \\
\text { laminectomy, need for discectomy }\end{array}$ \\
\hline $\begin{array}{l}\text { Katz et al. } \\
\text { (1996) }\end{array}$ & $\begin{array}{l}\text { Retrospective review } \\
\text { \& prospective } \\
\text { follow up }\end{array}$ & $88(55)$ & 8.1 & & $\begin{array}{l}\text { Rheumatoid arthritis } \\
\text { Old age }^{\dagger}\end{array}$ & $\begin{array}{l}\text { Age, sex, comorbidity, number of } \\
\text { segments decompressed, fusion, } \\
\text { preoperative neuromuscular deficits }\end{array}$ \\
\hline $\begin{array}{l}\text { Airaksinen } \\
\text { et al. (1997) }\end{array}$ & Retrospective & 438 & 4.3 & $\begin{array}{l}\text { Ability to work before or after } \\
\text { surgery } \\
\text { History of no prior back } \\
\text { surgery }\end{array}$ & $\begin{array}{l}\text { Diabetes, } \\
\text { Hip joint arthrosis } \\
\text { Preoperative fracture of the } \\
\text { lumbar spine }\end{array}$ & \\
\hline $\begin{array}{l}\text { Katz et al. } \\
\text { (1999) }\end{array}$ & Prospective & 199 & 2 & $\begin{array}{l}\text { Low cardiovascular } \\
\text { comorbidity }\end{array}$ & & $\begin{array}{l}\text { Neuromuscular deficits } \\
\text { Spondylolisthesis }\end{array}$ \\
\hline $\begin{array}{l}\text { Cornefjord } \\
\text { et al. }(2000)\end{array}$ & Retrospective & 96 & 7.1 & & & Concomitant fusion \\
\hline $\begin{array}{l}\text { Amundsen } \\
\text { et al. (2000) }\end{array}$ & Prospective & 32 & 10 & & & $\begin{array}{l}\text { Age } \\
\text { Advanced degenerative changes of } \\
\text { the spine }\end{array}$ \\
\hline $\begin{array}{l}\text { Hee et al. } \\
(2003)\end{array}$ & Retrospective & 68 & 8 & & $\begin{array}{l}\text { Hartshill rectangle } \\
\text { instrumentation } \\
\text { Preoperative leg numbness }\end{array}$ & $\begin{array}{l}\text { Age, sex, comorbidity score, } \\
\text { number of levels decompressed, } \\
\text { degenerative spondylolisthesis }\end{array}$ \\
\hline $\begin{array}{l}\text { Atlas et al. } \\
(2005)\end{array}$ & Prospective & 56 & $8-10$ & $\begin{array}{l}\text { Better baseline SF-36 social } \\
\text { function \& general health } \\
\text { status } \\
\text { Higher educational level" }\end{array}$ & Cigarette smoking $^{\S}$ & $\begin{array}{l}\text { Age, sex, employment, comorbidity, } \\
\text { symptom severity, physical } \\
\text { examination findings }\end{array}$ \\
\hline $\begin{array}{l}\text { Galiano } \\
\text { et al. (2005) }\end{array}$ & Retrospective & 23 & 2.7 & & Musculoskeletal comorbidity & \\
\hline $\begin{array}{l}\text { Gelalis } \\
\text { et al. (2006) }\end{array}$ & Retrospective & 50 & 11.6 & Concomitant fusion & $\begin{array}{l}\text { Prolonged preoperative } \\
\text { symptoms }\end{array}$ & \\
\hline $\begin{array}{l}\text { Yamashita } \\
\text { et al. (2006) }\end{array}$ & Prospective & 70 & 5 & & $\begin{array}{l}\text { Older age }(>65 \text { years }) \\
\text { Female }\end{array}$ & \\
\hline $\begin{array}{l}\text { Sinikallio } \\
\text { et al. (2009) }\end{array}$ & Prospective & 102 & 1 & & Depressive burden & \\
\hline $\begin{array}{l}\text { Kleinstuck } \\
\text { et al. (2009) }\end{array}$ & Prospective & 221 & 1 & & $\begin{array}{l}\text { Increasing preoperative LBP } \\
\text { intensity }\end{array}$ & \\
\hline $\begin{array}{l}\text { Bouras } \\
\text { et al. (2010) }\end{array}$ & Retrospective & $182(125)$ & 5 & & $\begin{array}{l}\text { Low back pain } \\
\text { Female }\end{array}$ & \\
\hline $\begin{array}{l}\text { Foulongne } \\
\text { et al. (2013) }\end{array}$ & Prospective & 98 & 5 & Low comorbidity & & \\
\hline
\end{tabular}

Abbreviations: N: number of patients. Numbers in parentheses mean patients responded last follow up. FU: follow up period in years.

${ }^{\dagger}$ Factors related with poor walking ability.

${ }^{\ddagger}$ Factors with no prognostic value for symptom severity and satisfaction.

"Factors increased the odds of satisfaction. No prognostic factor was identified in the study by Atlas et al. (2005)

${ }^{\S}$ Factor decreased the odds of a patient reporting long-term satisfaction. No prognostic factor was identified in the study by Atlas et al. (2005) 
spinal stenosis are in debate. Because most of the lumbar spinal stenosis are caused by degenerative process of the spine in accordance with aging and surgical treatments are usually considered in severe symptomatic patients of advanced stage of the disease, the characteristics of the patients include old age, advanced degenerative changes of musculoskeletal system as well as the spine, and multiple medical comorbidities. These factors may influence on selection of patients and modalities of surgery, anesthesia, postoperative care, and surgical outcome. Therefore, it seems reasonable to expect less favorable outcome in those patients with above features. However, the results in literatures were quite controversial (Tables 4,5 ).

\section{Age}

Age was one of the most frequently discussed prognostic factors in literature. Herno et al. indicated age below 50 years was a good prognostic factor ${ }^{26}$. Yamashita et al. also indicated old age as a poor prognostic factor. They mentioned that the only variable independently associated with deterioration in symptoms between the 24-month and 60-month follow-up evaluations was age and older age ( $>65$ years) predicted a greater risk of late recurrence of symptoms ${ }^{62)}$.

In 1996, Katz et al. reported poor walking ability associated with rheumatoid arthritis and old age. However, age was not related with symptom severity or satisfaction in their study and their following prospective study ${ }^{36,38)}$. Most of the other authors reported age was not associated with surgical outcome of lumbar spinal stenosis in accordance with Katz et al. ${ }^{2,925,36,56}$. Arinzon et al. studied two geriatric patient populations of aged 65-74 years and those more than 75 years of age. They reported improve pain and the ability to perform daily activities in both age groups postoperatively and concluded age is not a contraindication for decompressive lumbar spine surgery although both groups showed high rate of postoperative complication in comparing with other studies. In their study, postoperative complications were minor and mostly medical complications ${ }^{4}$. Long term surgical outcome for elderly patient were satisfactory in $65-81.6 \%$ of the patients which were comparable to results of younger population ${ }^{11,21,25)}$. Lee et al. compared surgical outcome of decompressive laminectomy and decompression with fusion for patients older than 75 years and concluded even in elderly patients, lumbar surgery was justifiable treatment for spinal stenosis even in elderly patients and concomitant fusion surgery had favorable outcome than decompressive surgery for patients who mainly complained of back pain ${ }^{43)}$. Furthermore, surgical treatment for lumbar spinal stenosis in elderly patients did not reduce their life expectancy. Kim et al. studied life expectancy after lumbar spine surgery for 1,015 Korean patients undergone lumbar spine surgery and 1- to 11-year follow up and indicated that overall 10 -year survival was $87.8 \%$ in $60-70$ years old, $83.8 \%$ in $70-85$ years old and standardized mortality ratios were $0.21,0.53$, and 0.45 in patients aged 50-59, 60-69, and $70-85$, respectively ${ }^{40}$. However, these mortality ratios were less than those of the corresponding portion of the general population.

\section{Gender}

Gender was another prognostic factor in debate. Yamashita et al. and Bouras et al. indicated female as a poor prognostic factor ${ }^{11,62)}$. But other authors indicated sex had no prognostic value $^{9,25,36,56)}$. The MLSS of 8 to 10 years follow up resulted that variables in all models included treatment group, age, and sex as well as other baseline variables with $p$ values $<0.2$ in adjusted models and no statistically significant independent predictors of satisfaction was identified. They only found better

Table 5. Radiologic prognostic factors of the surgical treatment for lumbar spinal stenosis

\begin{tabular}{|c|c|c|c|c|c|}
\hline Authors & Study design & $\mathrm{N}$ & $\mathrm{FU}$ & Favorable factors & Unfavorable factors \\
\hline $\begin{array}{l}\text { Caputy } \\
\text { et al. (1992) }\end{array}$ & Retrospective & 100 & $>5$ & & Associated spondylolisthesis \\
\hline $\begin{array}{l}\text { Jönsson } \\
\text { et al. (1997) }\end{array}$ & Prospective & 105 & 5 & $\begin{array}{l}\text { Canal AP diameter less than } 6 \mathrm{~mm} \\
\text { Shorter symptom duration }(<4 \text { years })\end{array}$ & \\
\hline $\begin{array}{l}\text { Hurri et al. } \\
\text { (1998) }\end{array}$ & Retrospective & 75 & 12 & & Severity of lumbar spinal stenosis ${ }^{\dagger}$ \\
\hline $\begin{array}{l}\text { Iguchi et al. } \\
\text { (2000) }\end{array}$ & Retrospective & 37 & 13.1 & & $\begin{array}{l}\text { Multiple level laminectomy } \\
>10 \text { degrees sagittal rotation angle }\end{array}$ \\
\hline $\begin{array}{l}\text { Xia et al. } \\
(2008)\end{array}$ & Retrospective & 49 & 6.33 & & $\begin{array}{l}\text { Decreasing preoperative lordosis angle } \\
\text { Decreasing lumbar ROM }\end{array}$ \\
\hline $\begin{array}{l}\text { Park et al. } \\
\text { (2010) }\end{array}$ & $\begin{array}{l}\text { Randomized trial and } \\
\text { observational cohort study }\end{array}$ & 716 & $>2$ & & $\begin{array}{l}\text { Multilevel stenosis with } \\
\text { spondylolisthesis }\end{array}$ \\
\hline $\begin{array}{l}\text { Blumenthal } \\
\text { et al. (2013) }\end{array}$ & Prospective & 40 & 3.6 & & $\begin{array}{l}\text { Facet angle }>50 \text { degrees } \\
\text { Disc height }>6.5 \mathrm{~mm} \\
\text { Motion at spondylolisthesis }>1.25 \mathrm{~mm}\end{array}$ \\
\hline
\end{tabular}

Abbreviations: $\mathrm{N}$ : number of patients. FU: follow up period in years.

${ }^{\dagger}$ The radiographic severity of lumbar spinal stenosis predicts disability independently of therapy regimen. 
baseline SF-36 social function and general health status and higher educational level increased the odds of satisfaction and cigarette smoking decreased the odds of a patient reporting long-term satisfaction with borderline statistical significance ${ }^{9)}$. However, in the study of postoperative life expectancy by Kim et al., female survived longer than male patients ${ }^{40}$.

\section{Comorbidity}

The studies conducted by Katz et al. in 1999 and Foulongne et al. indicated low comorbidity as a favorable prognostic factor ${ }^{19,38)}$. But the studies of other authors including the MLSS did not find comorbidity having prognostic value ${ }^{9,25,56}$. As mentioned earlier, surgical treatments for lumbar spinal stenosis are usually considered for severe symptomatic patients who are usually elderly and have several medical illnesses, comparison within this group of patients may be difficult to reveal significant differences in outcome according to comorbidity as well as age ${ }^{9,36,38)}$. However, it is quite obvious that postoperative management of patients with medical comorbidity is troublesome. Among the comorbidity, diabetes and hypertension may be most frequent diseases encountered in practice. Airaksinen et al. indicated diabetes as a poor prognostic factor and Arinzon et al. found patients with diabetes had higher in-hospital perioperative complication rate than control group $(67 \%$ vs $38 \%(p<0.001)^{1,3)}$.

Meanwhile, musculoskeletal comorbidity was also discussed by some authors. Galiano et al. pointed musculoskeletal comorbidity as a poor prognostic factor ${ }^{21)}$. Rheumatoid arthritis was found as an unfavorable factor by Katz et al. ${ }^{36}$. Hip joint arthrosis, and preoperative fracture of the lumbar spine were associated with poor outcome in another study ${ }^{1)}$.

\section{Preoperative Symptoms and Neurologic Deficits}

Among patients' symptoms, low back pain was an unfavorable factor in some studies ${ }^{11,41)}$. Patients with prolonged preoperative symptoms seemed to be less satisfied with the surgery ${ }^{22,35)}$. Preoperative leg numbness was a poor prognostic factor and history of no prior back surgery was a good prognostic factor reported by Airaksinen et al. ${ }^{1)}$. However, some authors failed to find any association of preoperative symptoms or neurologic deficits with surgical outcome $\mathrm{e}^{9,36,38,56)}$.

\section{Psychosocial Factors}

Airaksinen et al. pointed the ability to work before or after surgery as a good prognostic factor ${ }^{1)}$. On the contrary, the MLSS found employment to have no prognostic value ${ }^{9)}$. Worker's compensation had no role in prognosis of the study by Tuite et al. ${ }^{56}$. Depressive mood also played as poor prognostic factor. Sinikallio et al. conducted a study for 102 patients with lumbar spinal stenosis and average age of 62 years. They mentioned that the prevalence of depression was $18 \%$ and higher preoperative depressive burden scores were independently associated with a poorer self-reported functional ability, symptom severity, and a poorer walking capacity on 1-year follow-up ${ }^{53)}$.

\section{Radiologic Factors}

Jönsson et al. indicated a canal anteroposterior diameter less than $6 \mathrm{~mm}$ as a good prognostic factor ${ }^{35)}$. In contrast, Hurri et al. found the radiographic severity of lumbar spinal stenosis predicts disability independently of treatment in their 12 years follow up comparative study of operative and conservative treat$\operatorname{ment}^{27)}$. Some authors indicated multilevel lumbar spinal stenosis was a poor prognostic factor ${ }^{28)}$. However, the result of a multilevel lumbar stenosis subgroup analysis of the SPORT study concluded that multilevel spinal stenosis did not demonstrate worse baseline symptoms or worse treatment outcomes than isolated spinal stenosis. Therefore, the number of levels treated did not predict outcome ${ }^{47)}$.

Accompanying degenerative spondylolisthesis in lumbar spinal stenosis is common phenomenon especially in surgical patients. Prognostic value of associated spondylolisthesis in lumbar spinal stenosis is also controversial. Caputy et al. indicated associated spondylolisthesis as a poor prognostic factor ${ }^{12}$. Park et al. reported that when concomitant degenerative spondylolisthesis existed, patients with only single level stenosis tended to improve more than those with multilevel stenosis after surgery ${ }^{47)}$. Another studies did not find associated spondyolisthesis in lumbar spinal stenosis as a prognostic factor ${ }^{25,56}$.

Some authors postulated decreasing preoperative lumbar lordosis angle and lumbar range of motion, more than 10 degrees of sagittal rotation angle, more than 50 degrees of facet angle, disc height over $6.5 \mathrm{~mm}$, and motion at the spondylolisthetic level more than $1.25 \mathrm{~mm}$ as unfavorable prognostic factors $^{10,28,61)}$.

\section{Addition of Fusion after Decompression}

The need for additional fusion after decompression in surgical outcome was also controversial topic (Table 6). An overt preoperative instability in the segments to be decompressed may be generally considered as a solid indication to add concomitant fusion procedures. Postacchini et al. and Yone et al. reported unfavorable outcomes in patients treated by decompression alone in the presence of instability ${ }^{48,63)}$. However, Fox et al. conducted a retrospective study to assess postoperative radiologic instability following decompressive lumbar laminectomy. They included 124 patients with average 5.8 years follow up and 60 of the patients (48.8\%) had preoperative slippage. They found the radiological progression did not cor- 
relate well with patient-reported outcome albeit progressive postoperative spondylolisthesis occurred in $31 \%$ of the patients with normal preoperative alignment (mean $7.8 \mathrm{~mm}$ ) and in $73 \%$ of those with preoperative subluxation (mean $5.1 \mathrm{~mm}$ ) in whom fusion was not attained. Cornefjord et al. also concluded the patients with fusions, instrumented or non-instrumented, did not differ significantly from the unfused patients regarding outcome parameters ${ }^{14)}$. The results of two prospective studies, including 66 and 5,390 patients each, based on the National Swedish Register for Spine Surgery (Swespine) indicated the addition of fusion was not associated with an improved health related quality of life or outcome ${ }^{18,31)}$. Forsth et al. mentioned that in elderly patients with 1 or 2 level lumbar spinal stenosis, with or without a spondylolisthesis, surgery can probably be limited to decompression alone in order to avoid unnecessary complications.

Meanwhile, another authors indicated notable points on the benefit of fusion procedures. In 1997, Niggemeyer et al. conducted a meta-analysis of surgical procedures for degenerative lumbar spinal stenosis in literature from 1975 to 1995 . There were 30 articles including 1,668 patients with mean 4.7 years follow up and reported decompression with instrumented fusion had the best results in those with duration of symptoms of 15 years or more ${ }^{46)}$. Katz et al. reported superior relief of back pain up to 24 months postoperatively in non-instrumented arthrodesis albeit the difference was not significant ${ }^{37}$. Lee et al. studies 25 patients over aged 75 years undergone decompression with fusion and 25 age and sex matched decompression group. They found the decrease in back pain score after treatment was significantly greater in the decompression with fusion group compared to the decompression ${ }^{43)}$.

\section{Others}

Multilevel laminectomy was poor prognostic factor in a study of Iguchi et al. ${ }^{28}$. However, extent of laminectomy, need for discectomy, or number of levels decompressed were not prognostic according to other authors ${ }^{25,47,56)}$. The need for additional surgery was correlated with poor outcome in a study of Tuite et al. ${ }^{56}$.

Table 6. Role of fusion procedures in the surgical outcome of lumbar spinal stenosis

\begin{tabular}{|c|c|c|c|c|c|c|c|}
\hline $\begin{array}{l}\text { Authors } \\
\text { (Year) }\end{array}$ & Study design & $\mathrm{N}$ & $\operatorname{Age}^{\dagger}$ & $\mathrm{FU}$ & Spondylolisthesis & Operations & Favors fusion \\
\hline $\begin{array}{l}\text { Postacchini } \\
\text { et al. (1992) }\end{array}$ & Retrospective & 40 & 54 & 8.6 & $\begin{array}{l}16 \text { spondylolisthesis } \\
(53.3 \%)\end{array}$ & $\begin{array}{l}30 \text { decompression } \\
10 \text { fusion }(25 \%)\end{array}$ & $\begin{array}{l}\text { Group with degenerative } \\
\text { spondylolisthesis }\end{array}$ \\
\hline $\begin{array}{l}\text { Fox et al. } \\
\text { (1996) }\end{array}$ & Retrospective & 124 & 67.5 & 5.8 & 60 slippage (48.4\%) & $\begin{array}{l}92 \text { decompression } \\
32 \text { fusion }(26 \%)\end{array}$ & $\begin{array}{l}\text { No difference in outcome } \\
\text { according to fusion }\end{array}$ \\
\hline $\begin{array}{l}\text { Katz et al. } \\
\text { (1997) }\end{array}$ & Retrospective & 272 & $70,64,66^{\ddagger}$ & 2 & $\begin{array}{l}\geq 5 \mathrm{~mm} \text { listhesis; } \\
(23 \%, 70 \%, 54 \%)^{\ddagger} \\
\geq 15^{\circ} \text { scoliosis; } \\
(7 \%, 3 \%, 13 \%)^{\dagger}\end{array}$ & $\begin{array}{l}194 \text { decompression } \\
37 \text { uninstrumented fusion (14\%) } \\
41 \text { instrumented fusion (15\%) }\end{array}$ & $\begin{array}{l}\text { Favorable outcome in } \\
\text { ) uninstrumented fusion }\end{array}$ \\
\hline $\begin{array}{l}\text { Niggemeyer } \\
\text { et al. (1997) }\end{array}$ & Meta-analysis & 1,668 & 55.7 & 4.7 & NA & $\begin{array}{l}1,476 \text { decompression } \\
49 \text { uninstrumented fusion ( } 4 \%) \\
243 \text { instrumented fusion }(15 \%)\end{array}$ & $\begin{array}{l}\text { Group with a duration of } \\
\text { symptoms of } 15 \text { years } \\
\text { or more }\end{array}$ \\
\hline $\begin{array}{l}\text { Rompe et al. } \\
\text { (1999) }\end{array}$ & Retrospective & 117 & 61 & 8 & $\begin{array}{l}\geq 5 \mathrm{~mm} \text { olisthesis; } \\
(20 \%, 34 \%, 81 \%)^{\S} \\
\geq 15^{\circ} \text { scoliosis; } \\
(10 \%, 14 \%, 19 \%)^{\S}\end{array}$ & $\begin{array}{l}39 \text { undercutting } \\
51 \text { laminectomy } \\
27 \text { laminectomy and fusion }(23 \%)\end{array}$ & $\begin{array}{l}\text { Less favorable outcome in } \\
\text { laminectomy and fusion } \\
\text { group }\end{array}$ \\
\hline $\begin{array}{l}\text { Cornefjord } \\
\text { et al. }(2000)\end{array}$ & Retrospective & 96 & 64.4 & 7.1 & $\begin{array}{l}27 \text { spondylolisthesis } \\
(28 \%)\end{array}$ & $\begin{array}{l}37 \text { decompression } \\
17 \text { uninstrumented fusion (18\%) } \\
42 \text { instrumented fusion ( } 44 \%)\end{array}$ & $\begin{array}{l}\text { No difference in } \\
\text { satisfaction according to } \\
\text { fusion }\end{array}$ \\
\hline $\begin{array}{l}\text { Jansson et al. } \\
\text { (2009) }\end{array}$ & Prospective & 230 & 66 & 1 & NA & $\begin{array}{l}177 \text { decompression } \\
49 \text { fusion }(21 \%) \\
4 \text { other }\end{array}$ & $\begin{array}{l}\text { No difference in health } \\
\text { related quality of life } \\
\text { according to fusion }\end{array}$ \\
\hline $\begin{array}{l}\text { Lee et al. } \\
(2013)\end{array}$ & Retrospective & 50 & $79.2,79.7^{\natural}$ & 3.9 & NA & $\begin{array}{l}25 \text { decompression } \\
25 \text { fusion }(50 \%)\end{array}$ & $\begin{array}{l}\text { Favorable back pain } \\
\text { outcome in fusion group }\end{array}$ \\
\hline $\begin{array}{l}\text { Forsth et al. } \\
(2013)\end{array}$ & $\begin{array}{l}\text { Prospective } \\
\text { cohort }\end{array}$ & 5,390 & $70,67^{9}$ & 2 & $\begin{array}{l}15 \% \text { in decompression } \\
59 \% \text { in fusion }\end{array}$ & $\begin{array}{l}4,259 \text { decompression } \\
1,131 \text { fusion }(21 \%)\end{array}$ & $\begin{array}{l}\text { No difference in satisfac- } \\
\text { tion according to fusion }\end{array}$ \\
\hline
\end{tabular}




\section{REPEATED SURGERY}

Sanderson et al. reported no revision surgery in their retrospective series of partial undercutting facetectomy for lumbar lateral recess stenosis. There were 57 patients with average 8.4 years follow up. However, most researchers have reported repeated surgeries in their studies regardless of surgical modalities (Table 7). The reoperation rates were varied from 3.7\% to $23 \%$ in retrospective studies $3,4,12,14,21,25,36,43,50,56,61)$, from $6.2 \%$ to $35 \%$ in prospective studies ${ }^{9,10,18,19,32)}$, and from 4 to $13 \%$ in randomized trials ${ }^{1,44,47,49,59)}$. According to population based studies, cumulative reoperation rates were ranged $2-7.2 \%$ within one year, $5-9.4 \%$ within 2 years, $8-14.2 \%$ within 5 years, and $11-22.9 \%$ within 10 years postoperatively (Table 8$)^{16,30,39,45}$. In addition, the results of a study of 5,699 patients undergone surgical treatment during 1990 to 1993 in Washington state and another study of 11,027 Korean patients undergone surgery in 2003 showed similar sigmoid pattern of increasing cumulative reoperation rates ${ }^{39,45}$. The reoperation rate increased markedly during first postoperative year and slowly increased later on. It did not reach to plateau. Kim et al. calculated a formula of the crude reoperation rate at each time (Reoperation rate $=5.75+1.71 \times$ postoperative year, $\mathrm{R}^{2}=0.99$ ) and estimated 10 -year reoperation rate would be $22.9 \%{ }^{39}$ ) . A subgroup analysis of the SPORT study, which stratified the patients according to those who had reoperation $(n=54)$ or no reoperation $(\mathrm{n}=359)$, found only risk factor for reoperation was pretreatment symptom duration more than 12 months. They concluded that reoperation might be related to the natural history of spinal degenerative disease ${ }^{49)}$. These findings suggest that major causes of repeated operations may be related with surgery itself during early postoperative period but in following years, natural history of lumbar spinal stenosis may play more important role. Hence, overall reoperation rates of surgical treatment for lumbar spinal stenosis seem to be roughly $10-15 \%$ and about half of the reoperation occurs within the first postoperative year. The annual reoperation rate in following years may be $0.5-1.5 \%$ per year.

\section{Risk Factors for Repeated Surgery}

An old age was not suggestive of a risk factor. Arinzon

Table 7. Summary of reoperation rates in the studies of lumbar spinal stenosis

\begin{tabular}{|c|c|c|c|}
\hline Authors (Year) & No. of patients & Follow up period (years) & Reoperation rate \\
\hline \multicolumn{4}{|l|}{ Retrospective studies } \\
\hline Caputy et al. (1992) & 100 & $>5$ & $16 \%$ \\
\hline Tuite et al. (1994) & 119 & 4.6 & $15 \%$ \\
\hline Katz et al. (1996) & 88 & 8.1 & $23 \%$ \\
\hline Rompe et al. (1999) & 117 & 8 & $15.3 \%$ \\
\hline Cornefjord et al. (2000) & 96 & 7.1 & $13.5 \%$ \\
\hline Hee et al. (2003) & 68 & 8 & $7.4 \%$ \\
\hline Arinzon et al. (2003) & $235(152$ aged $65-74,83$ aged $>75)$ & $\begin{array}{l}41.5 \text { months (aged 65-74) } \\
42.9 \text { months (aged >75) }\end{array}$ & $\begin{array}{l}9.9 \%(\text { aged } 65-74) \\
8.4 \%(\text { aged }>75)\end{array}$ \\
\hline Arinzon et al. (2004) & 124 (62 diabetic, 62 control) & 41 months & $11.3 \%$ (16.1\% diabetic, $6.5 \%$ control) \\
\hline Galiano et al. (2005) & 23 & 2.7 & $3.7 \%$ \\
\hline Xia et al. (2008) & 49 & 6.33 & $8.2 \%$ \\
\hline Lee et al. (2013) & 50 (aged >75 years) & 2 & $12 \%$ \\
\hline \multicolumn{4}{|l|}{ Prospective studies } \\
\hline Javid et al. (1998) & 170 & 5.1 & $6.5 \%$ \\
\hline Atlas et al. (2005) & 56 & 8 to 10 & $23 \%$ \\
\hline Forsth et al. (2013) & $\begin{array}{c}5,390 \text { (4,259 decompression, } \\
\text { 1,131 added fusion) }\end{array}$ & 2 & $\begin{array}{l}\text { 7.0\% decompression } \\
8.1 \% \text { added fusion }\end{array}$ \\
\hline Foulongne et al. (2013) & 98 & 5 & $10.2 \%$ \\
\hline Blumenthal et al. (2013) & 40 & 3.6 & $35 \%$ \\
\hline \multicolumn{4}{|l|}{ Randomized trials } \\
\hline Malmivaara et al. (2007) & 50 & 2 & $4 \%$ \\
\hline Weinstein et al. (2010) & 419 & 4 & $13 \%$ \\
\hline Park et al. (2010) & 716 & $>2$ & $10.1 \%$ \\
\hline Radcliff et al. (2013) & 413 & 4 & $13 \%$ \\
\hline
\end{tabular}


Table 8. Summary of repeated surgery in the population based studies for lumbar spinal stenosis

\begin{tabular}{|c|c|c|c|c|c|c|}
\hline $\begin{array}{l}\text { Authors } \\
\text { (Year) }\end{array}$ & Study population & $\mathrm{N}$ & FU & Reoperation rate & $\begin{array}{l}\text { Cumulative reoperation } \\
\text { rate }\end{array}$ & Risk factors \\
\hline $\begin{array}{l}\text { Jansson } \\
\text { et al. } \\
(2005)\end{array}$ & $\begin{array}{l}\text { Swedish National } \\
\text { Inpatient Registry } \\
(1987-1999)\end{array}$ & 9,664 & 10 & $11 \%$ at 10 years & $\begin{array}{l}\text { Within } 30 \text { days; } 0.15 \% \\
1 \text { year: } 2 \% \\
2 \text { years: } 5 \% \\
5 \text { years: } 8 \% \\
10 \text { years: } 11 \%\end{array}$ & $\begin{array}{l}\text { Adding a fusion may lower the } \\
\text { reoperation risk }\end{array}$ \\
\hline $\begin{array}{l}\text { Martin } \\
\text { et al. } \\
(2007)\end{array}$ & $\begin{array}{l}\text { Comprehensive Hospital } \\
\text { Abstract Reporting } \\
\text { System (Washington } \\
\text { state, USA; 1990-1993) }\end{array}$ & 5,699 & 11 & $\begin{array}{c}16.8 \% \\
\text { (decompression } \\
\text { alone) } \\
19.9 \% \text { (initial fusion) }\end{array}$ & & $\begin{array}{l}\text { Worker's compensation HR } 1.27 \\
\text { Age (<age } 60) \text { HR } 1.46\end{array}$ \\
\hline $\begin{array}{l}\text { Deyo } \\
\text { et al. } \\
(2011)\end{array}$ & $\begin{array}{l}\text { Medicare Provider } \\
\text { Analysis and Review } \\
\text { (aged >68) }\end{array}$ & 31,543 & 4 & $11.7 \%$ at 4 years & $\begin{array}{l}1 \text { year: } 4.1 \% \\
2 \text { years: } 7.1 \% \\
3 \text { years: } 9.3 \% \\
4 \text { years: } 11.0 \%\end{array}$ & $\begin{array}{l}\text { Previous lumbar surgery }(17.2 \% \\
\text { vs. } 10.6 \% \text { in patients with no } \\
\text { prior surgery: } p<0.001)\end{array}$ \\
\hline $\begin{array}{l}\text { Kim et al. } \\
(2013)\end{array}$ & $\begin{array}{l}\text { Korean National Health } \\
\text { Insurance (2003) }\end{array}$ & 11,027 & 6 & $14.2 \%$ at 5 years & $\begin{array}{l}3 \text { months: } 4.7 \% \\
1 \text { year: } 7.2 \% \\
2 \text { years: } 9.4 \% \\
3 \text { years: } 11.2 \% \\
4 \text { years: } 12.5 \% \\
5 \text { years: } 14.2 \% \\
\text { Expected rate: } 22.9 \% \text { at } 10 \\
\text { years }\end{array}$ & $\begin{array}{l}\text { Early ( }<90 \text { days): male, } \\
\text { comorbidity, hospital type } \\
\text { Short term ( } 3-12 \text { months): male, } \\
\text { diabetes, comorbidity } \\
\text { Mid-term (1-6 years): diabetes, } \\
\text { comorbidity, hospital type }\end{array}$ \\
\hline
\end{tabular}

Abbreviations: $\mathrm{N}$ : number of patients. FU: follow up period in years. HR: the hazard ratio

et al. reported reoperation rates were $9.9 \%$ for aged $65-74$ years group and $8.4 \%$ for aged more than 75 years group4. Lee et al. reported $12 \%$ reoperation rate in 50 patients aged more than 75 years $^{43}$. These rates were not higher in comparing the results of other studies. Furthermore, Deyo et al. found the reoperation rate fell with increasing patient age in their population based study ${ }^{16}$. Martin et al. also reported age younger than 60 years old was a significant risk factor to have second operations with the hazard ratio of $1.46(95 \% \mathrm{CI}, 1.34-1.59)^{45}$.

Diabetes was a risk factor in a Korean population based study $^{39)}$. Arinzon et al. reported reoperation rates were $16.1 \%$ in diabetic patients and $6.5 \%$ in control in their retrospective study enrolled 62 diabetic and 62 control patients of aged more than 65 years ${ }^{3)}$. Comorbidity was reported as a risk factor for reoperation by Kim et al. However, the reoperation rate decreased with increasing patient comorbidity in a study by Deyo et al. ${ }^{16,39)}$.

Adding fusion procedures after decompression was also controversial issue in repeated surgery. A Swedish register study including 5,390 patients with two years follow up found no significant difference in reoperation rates in decompression alone versus decompression and fusion groups (7\% vs. $8.1 \%$ respectively) ${ }^{18)}$. Radcliff et al. also indicated lumbar fusion and instrumentation were not associated with increased rate of reoperation compared with non-fusion techniques in subgroup analysis of the SPORT study ${ }^{49}$. A Korean population based study also denied fusion procedures as a risk factor to increase reoperation rate ${ }^{39)}$. Furthermore, a Swedish nationwide study of 10 years follow up indicated adding a fusion might lower the reoperation risk. The number of reoperations per person years was higher in patients with laminectomy than those with fusion (0.016 times/person-year for laminectomy vs. 0.012 times/ person-year for fusion). The difference was not significant ${ }^{30}$.

The other risk factors for subsequent operation were worker's compensation and previous history of lumbar surgery ${ }^{16,45)}$. A Korean population based study reported risk factors of reoperation according to postoperative periods. The early (within 90 days) risk factors were male, comorbidity, and hospital type. The short-term (within 1 year) risk factors were male, diabetes, and comorbidity. The mid-term (within 6 years) risk factors were diabetes, comorbidity, and hospital type ${ }^{39)}$.

\section{COMPLICATIONS}

\section{Mortality}

Perioperative mortality rate of surgical treatment for lumbar spinal stenosis was $0.2 \%$ in 4 years follow up study of the SPORT and $0.7 \%$ in their subgroup of multilevel lumbar spinal stenosis $^{47,59)}$. In a study by Deyo et al. which included 32,152 patients aged 66 years and older with Medicare claim after surgery for lumbar spinal stenosis, mortality rate within 30 days of discharge was $0.4 \%$ in all patients. According to types of surgery, mortality rate within 30 days of discharge was $0.3 \%$ in patients with decompression alone, $0.5 \%$ in simple 
Table 9. Summary of complication rate in the studies for lumbar spinal stenosis

\begin{tabular}{|c|c|c|c|}
\hline Authors (Year) & $\mathrm{N}$ & FU & Complication rate \\
\hline Sanderson et al. (1996) & 57 & 8.4 & $5.3 \%$ \\
\hline Fox et al. (1996) & 124 & 5.8 & $21.8 \%$ \\
\hline Airaksinen et al. (1997) & 438 & 4.3 & $11 \%$ \\
\hline Javid et al. (1998) & 170 & 5.1 & $2.4 \%$ \\
\hline Cornefjord et al. (2000) & 96 & 7.1 & $7.3 \%$ \\
\hline Jolles et al. (2001) & 77 & 6.5 & $14 \%$ \\
\hline Arinzon et al. (2003) & 235 (152 aged $65-74,83$ aged $>75)$ & $\begin{array}{l}3.5(\text { aged } 65-74) \\
3.6(\text { aged }>75)\end{array}$ & $\begin{array}{l}41.3 \%(\text { aged } 65-74) \\
46.7 \%(\text { aged }>75)\end{array}$ \\
\hline Arinzon et al. (2004) & 124 (62 diabetic, 62 control group) & 3.4 & $45 \%$ (67\% diabetic, $38 \%$ control) \\
\hline Galiano et al. (2005) & 23 & 2.7 & $17.4 \%$ \\
\hline Malmivaara et al. (2007) & 50 & 2 & $24 \%$ \\
\hline Weinstein et al. (2010) & 419 & 4 & $18.6 \%$ \\
\hline Park et al. (2010) & 716 & $>2$ & $22.2 \%$ \\
\hline Lee et al. (2013) & 50 & 2 & $10 \%$ \\
\hline Foulongne et al. (2013) & 98 & 5 & $4.1 \%$ \\
\hline Blumenthal et al. (2013) & 40 & 3.6 & $5 \%$ \\
\hline
\end{tabular}

Abbreviations: $\mathrm{N}$ : number of patients. FU: follow up period in years.

fusion (1 or 2 disc levels, single surgical approach), and 0.6\% in complex fusion (more than 2 disc levels or combined anterior and posterior approach) ${ }^{17}$. Kim et al. reported the standardized mortality ratios of the patients with lumbar spine surgery were not different from the adjusted general population ${ }^{40)}$.

\section{Complication Rate}

Postoperative complications in literature varied from $2 \%$ to more than $40 \%$ according to characteristics of study populations (Table 9) $)^{1,3,4,10,14,19,21,32,34,43,44,47,59)}$. There were some exceptional studies reporting absence of complications ${ }^{2,12)}$. Arinzon et al. reported very high complication rate in elderly patients to be $41 \%$ in patients aged $65-74$ years and $47 \%$ in those aged more than 75 years ${ }^{4}$. Furthermore, the same institute reported complication rate of diabetic patients was $67 \%$ and that of control group was $38 \%{ }^{3}$. In both of the studies, the majority of complications were medical complications. A randomized controlled trial by Malmivaara et al. showed overall complication rate of 50 surgical patients was $24 \%{ }^{44)}$. In the SPORT study of 4 years follow up, complication rate of 419 surgical patients was $18.6 \%$ and in their subgroup study for multilevel lumbar spinal stenosis, complication rate was $22.2 \%{ }^{47,59)}$. The most frequently encountered surgical complications were dural tear, superficial wound infection, wound hematoma, and postoperative neurologic deficits etc. Deyo et al. indicated major medical complications in $3.1 \%$ and wound complication in $1.2 \%$ of 32,152 patients aged 66 years and older. They also found that age, comorbidity, and previous hospitalizations remained independently associated with lifethreatening complications and history of previous spine sur- gery was strongly associated with wound complications. Lifethreatening complications increased with increasing surgical invasiveness and the odds ratio of simple fusion was $1.93(95 \%$ CI, 1.21-3.08) and that of complex fusion was 2.56 (95\% CI, 1.61-4.09) for life-threatening complications, compared to decompression alone ${ }^{17)}$.

\section{POSTOPERATIVE INSTABILITY}

In 1996, Fox et al. studied radiological instability following decompression laminectomy with or without fusion for 124 patients with lumbar spinal stenosis and average 5.8 years follow up. They found progressive postoperative spondylolisthesis occurred in $31 \%$ of patients with normal preoperative alignment and in $73 \%$ of patients with preoperative subluxation in whom fusion was not attained. In their study, radiological progression of spondylolisthesis did not correlate with clinical outcome $^{20)}$. Blumenthal et al. conducted a prospective study including 40 patients having grade I spondylolisthesis with symptomatic lumbar spinal stenosis. They excluded those with mechanical back pain or with gross motion $(>3 \mathrm{~mm}$ ) on flexionextension lumbar radiographs and performed decompression alone. Postoperative instability at the index level was occurred in $15 / 40(35 \%)$ of the patients and all of them underwent reoperation. The risk factors were motion at spondylolisthesis $>1.25 \mathrm{~mm}$, disc height $>6.5 \mathrm{~mm}$, and facet angle $>50$ degrees $^{10}$.

\section{BLADDER FUNCTION AFTER DECOMPRESSIVE SURGERY}

The prevalence of lower urinary tract symptoms in patients 
with lumbar spinal stenosis was known to be from $50 \%$ to $80 \%{ }^{15,29)}$. Inui et al. demonstrated $40 \%$ of patients with lumbar spinal stenosis or disc herniation had no subjective urological symptoms but they revealed neurogenic dysfunction in urodynamic studies ${ }^{29)}$. Therefore, asymptomatic bladder dysfunction may be frequent in patients with lumbar spinal stenosis or disc. Some authors reported the prevalence of neuropathic bladder is more significantly associated with dural sac anteroposterior diameter in lumbar spinal stenosis ${ }^{29,55)}$.

Deen et al. demonstrated bladder function was subjectively improved in $60 \%$ of patients with lumbar decompressive laminectomy for spinal stenosis at the 6-month follow-up review ${ }^{15}$. Accordingly, another authors reported postoperative recovery rate of unrinary function was varied from 60 to $89 \%$ in patients with cauda equina syndrome ${ }^{13)}$. Among parameters of urodynamic study, post-voiding residual urine volume was reduced significantly after surgical decompression ${ }^{15,55)}$.

\section{CONCLUSION}

The results of studies comparing surgical and conservative treatment for lumbar spinal stenosis have supported sufficient evidence to accept benefit of surgical decompression with or without fusion in the patients with severe pain and disabilities. Successful long term outcome after decompressive surgery for lumbar spinal stenosis may be expected to more than two third of the patient but the benefit from surgery may decline during follow up. Many prognostic factors are postulated but most of them are in debate and any solid prognostic factor has not been identified. Though many authors reported concomitant fusion was not related with outcome and reoperation rate, it is recommended in patients with overt preoperative instability because concomitant fusion may increase postoperative complication rate especially in elderly patients. Overall reoperation rates of surgical treatment for lumbar spinal stenosis seem to be roughly $10-15 \%$ and about a half of the reoperation occurs within the first postoperative year. Postoperative complication rates may be expected in $10-20 \%$ of the patients and about a half of them is surgical complication of which may be avoidable. Occurrence or progression of postoperative instability is not uncommon in patients with decompressive surgery even in those with no preoperative instability. Bladder dysfunction may be benefited from decompressive surgery.

\section{- Acknowledgements}

This research was supported by a grant of the Korean Health Technology R\&D Project through the Korea Health Industry Development Institute (KHIDI) funded by the Ministry of Health \& Welfare, Republic of Korea (HC15C1320)

\section{REFERENCES}

1. Airaksinen O, Herno A, Turunen V, Saari T, Suomlainen O: Sur- gical outcome of 438 patients treated surgically for lumbar spinal stenosis. Spine (Phila Pa 1976) 22:2278-2282, 1997

2. Amundsen T, Weber H, Nordal HJ, Magnaes B, Abdelnoor M, Lilleas F: Lumbar spinal stenosis: conservative or surgical management?: A prospective 10-year study. Spine (Phila Pa 1976) 25: 1424-1435; discussion 1435-1426, 2000

3. Arinzon Z, Adunsky A, Fidelman Z, Gepstein R: Outcomes of decompression surgery for lumbar spinal stenosis in elderly diabetic patients. Eur Spine J 13:32-37, 2004

4. Arinzon ZH, Fredman B, Zohar E, Shabat S, Feldman JS, Jedeikin $\mathrm{R}$, et al.: Surgical management of spinal stenosis: a comparison of immediate and long term outcome in two geriatric patient populations. Arch Gerontol Geriatr 36:273-279, 2003

5. Athiviraham A, Yen D: Is spinal stenosis better treated surgically or nonsurgically? Clin Orthop Relat Res 458:90-93, 2007

6. Atlas SJ, Deyo RA, Keller RB, Chapin AM, Patrick DL, Long JM, et al.: The Maine Lumbar Spine Study, Part II. 1-year outcomes of surgical and nonsurgical management of sciatica. Spine (Phila Pa 1976) 21:1777-1786, 1996

7. Atlas SJ, Deyo RA, Keller RB, Chapin AM, Patrick DL, Long JM, et al.: The Maine Lumbar Spine Study, Part III. 1-year outcomes of surgical and nonsurgical management of lumbar spinal stenosis. Spine (Phila Pa 1976) 21:1787-1794; discussion 17941785, 1996

8. Atlas SJ, Keller RB, Robson D, Deyo RA, Singer DE: Surgical and nonsurgical management of lumbar spinal stenosis: four-year outcomes from the maine lumbar spine study. Spine (Phila Pa 1976) 25:556-562, 2000

9. Atlas SJ, Keller RB, Wu YA, Deyo RA, Singer DE: Long-term outcomes of surgical and nonsurgical management of lumbar spinal stenosis: 8 to 10 year results from the maine lumbar spine study. Spine (Phila Pa 1976) 30:936-943, 2005

10. Blumenthal C, Curran J, Benzel EC, Potter R, Magge SN, Harrington JF, Jr., et al.: Radiographic predictors of delayed instability following decompression without fusion for degenerative grade I lumbar spondylolisthesis. J Neurosurg Spine 18:340-346, 2013

11. Bouras T, Stranjalis G, Loufardaki M, Sourtzis I, Stavrinou LC, Sakas DE: Predictors of long-term outcome in an elderly group after laminectomy for lumbar stenosis. J Neurosurg Spine 13: 329-334, 2010

12. Caputy AJ, Luessenhop AJ: Long-term evaluation of decompressive surgery for degenerative lumbar stenosis. J Neurosurg 77:669676, 1992

13. Cong ML, Gong WM, Zhang QG, Sun BW, Liu SH, Li L, et al.: Urodynamic study of bladder function for patients with lumbar spinal stenosis treated by surgical decompression. J Int Med Res 38:1149-1155, 2010

14. Cornefjord M, Byrod G, Brisby H, Rydevik B: A long-term (4to 12-year) follow-up study of surgical treatment of lumbar spinal stenosis. Eur Spine J 9:563-570, 2000

15. Deen HG, Jr., Zimmerman RS, Swanson SK, Larson TR: Assessment of bladder function after lumbar decompressive laminectomy for spinal stenosis: a prospective study. J Neurosurg 80:971-974, 1994

16. Deyo RA, Martin BI, Kreuter W, Jarvik JG, Angier H, Mirza SK: Revision surgery following operations for lumbar stenosis. J Bone Joint Surg Am 93:1979-1986, 2011

17. Deyo RA, Mirza SK, Martin BI, Kreuter W, Goodman DC, Jarvik JG: Trends, major medical complications, and charges associated with surgery for lumbar spinal stenosis in older adults. JAMA 303:1259-1265, 2010 
18. Forsth P, Michaelsson K, Sanden B: Does fusion improve the outcome after decompressive surgery for lumbar spinal stenosis?: A two-year follow-up study involving 5,390 patients. Bone Joint J 95-B:960-965, 2013

19. Foulongne E, Derrey S, Ould Slimane M, Leveque S, Tobenas AC, Dujardin F, et al.: Lumbar spinal stenosis: which predictive factors of favorable functional results after decompressive laminectomy? Neurochirurgie 59:23-29, 2013

20. Fox MW, Onofrio BM, Onofrio BM, Hanssen AD: Clinical outcomes and radiological instability following decompressive lumbar laminectomy for degenerative spinal stenosis: a comparison of patients undergoing concomitant arthrodesis versus decompression alone. J Neurosurg 85:793-802, 1996

21. Galiano K, Obwegeser AA, Gabl MV, Bauer R, Twerdy K: Longterm outcome of laminectomy for spinal stenosis in octogenarians. Spine (Phila Pa 1976) 30:332-335, 2005

22. Gelalis ID, Stafilas KS, Korompilias AV, Zacharis KC, Beris AE, Xenakis TA: Decompressive surgery for degenerative lumbar spinal stenosis: long-term results. Int Orthop 30:59-63, 2006

23. Gibson JN, Waddell G, Grant IC: Surgery for degenerative lumbar spondylosis. Cochrane Database Syst Rev: CD001352, 2000

24. Grob D, Humke T, Dvorak J: Degenerative lumbar spinal stenosis. Decompression with and without arthrodesis. J Bone Joint Surg Am 77:1036-1041, 1995

25. Hee HT, Wong HK: The long-term results of surgical treatment for spinal stenosis in the elderly. Singapore Med J 44:175-180, 2003

26. Herno A, Airaksinen O, Saari T: Long-term results of surgical treatment of lumbar spinal stenosis. Spine (Phila Pa 1976) 18: 1471-1474, 1993

27. Hurri H, Slatis P, Soini J, Tallroth K, Alaranta H, Laine T, et al.: Lumbar spinal stenosis: assessment of long-term outcome 12 years after operative and conservative treatment. J Spinal Disord 11:110-115, 1998

28. Iguchi T, Kurihara A, Nakayama J, Sato K, Kurosaka M, Yamasaki K: Minimum 10-year outcome of decompressive laminectomy for degenerative lumbar spinal stenosis. Spine (Phila Pa 1976) 25:1754-1759, 2000

29. Inui Y, Doita M, Ouchi K, Tsukuda M, Fujita N, Kurosaka M: Clinical and radiologic features of lumbar spinal stenosis and disc herniation with neuropathic bladder. Spine (Phila Pa 1976) 29: 869-873, 2004

30. Jansson KA, Nemeth G, Granath F, Blomqvist P: Spinal stenosis re-operation rate in Sweden is $11 \%$ at 10 years--a national analysis of 9,664 operations. Eur Spine J 14:659-663, 2005

31. Jansson KA, Nemeth G, Granath F, Jonsson B, Blomqvist P: Health-related quality of life (EQ-5D) before and one year after surgery for lumbar spinal stenosis. J Bone Joint Surg Br 91:210216, 2009

32. Javid MJ, Hadar EJ: Long-term follow-up review of patients who underwent laminectomy for lumbar stenosis: a prospective study. J Neurosurg 89:1-7, 1998

33. Johnsson KE, Uden A, Rosen I: The effect of decompression on the natural course of spinal stenosis. A comparison of surgically treated and untreated patients. Spine (Phila Pa 1976) 16:615-619, 1991

34. Jolles BM, Porchet F, Theumann N: Surgical treatment of lumbar spinal stenosis. Five-year follow-up. J Bone Joint Surg $\mathrm{Br}$ 83:949953, 2001

35. Jonsson B, Annertz M, Sjoberg C, Stromqvist B: A prospective and consecutive study of surgically treated lumbar spinal stenosis.
Part II: Five-year follow-up by an independent observer. Spine (Phila Pa 1976) 22:2938-2944, 1997

36. Katz JN, Lipson SJ, Chang LC, Levine SA, Fossel AH, Liang $\mathrm{MH}$ : Seven- to 10-year outcome of decompressive surgery for degenerative lumbar spinal stenosis. Spine (Phila Pa 1976) 21: 92-98, 1996

37. Katz JN, Lipson SJ, Lew RA, Grobler LJ, Weinstein JN, Brick GW, et al.: Lumbar laminectomy alone or with instrumented or noninstrumented arthrodesis in degenerative lumbar spinal stenosis. Patient selection, costs, and surgical outcomes. Spine (Phila Pa 1976) 22:1123-1131, 1997

38. Katz JN, Stucki G, Lipson SJ, Fossel AH, Grobler LJ, Weinstein $\mathrm{JN}$ : Predictors of surgical outcome in degenerative lumbar spinal stenosis. Spine (Phila Pa 1976) 24:2229-2233, 1999

39. Kim CH, Chung CK, Park CS, Choi B, Hahn S, Kim MJ, et al.: Reoperation rate after surgery for lumbar spinal stenosis without spondylolisthesis: a nationwide cohort study. Spine J 13: 1230-1237, 2013

40. Kim HJ, Lee HM, Kim HS, Moon ES, Park JO, Lee KJ, et al.: Life expectancy after lumbar spine surgery: one- to eleven-year follow-up of 1015 patients. Spine (Phila Pa 1976) 33:2116-2121; discussion 2122-2113, 2008

41. Kleinstuck FS, Grob D, Lattig F, Bartanusz V, Porchet F, Jeszenszky D, et al.: The influence of preoperative back pain on the outcome of lumbar decompression surgery. Spine (Phila Pa 1976) 34:1198-1203, 2009

42. Kreiner DS, Shaffer WO, Baisden JL, Gilbert TJ, Summers JT, Toton JF, et al.: An evidence-based clinical guideline for the diagnosis and treatment of degenerative lumbar spinal stenosis (update). Spine J 13:734-743, 2013

43. Lee CH, Hyun SJ, Kim KJ, Jahng TA, Kim HJ: Decompression only versus fusion surgery for lumbar stenosis in elderly patients over 75 years old: which is reasonable? Neurol Med Chir (Tokyo) 53:870-874, 2013

44. Malmivaara A, Slatis P, Heliovaara M, Sainio P, Kinnunen H, Kankare J, et al.: Surgical or nonoperative treatment for lumbar spinal stenosis? A randomized controlled trial. Spine (Phila Pa 1976) 32:1-8, 2007

45. Martin BI, Mirza SK, Comstock BA, Gray DT, Kreuter W, Deyo RA: Reoperation rates following lumbar spine surgery and the influence of spinal fusion procedures. Spine (Phila Pa 1976) 32: 382-387, 2007

46. Niggemeyer O, Strauss JM, Schulitz KP: Comparison of surgical procedures for degenerative lumbar spinal stenosis: a meta-analysis of the literature from 1975 to 1995. Eur Spine J 6:423-429, 1997

47. Park DK, An HS, Lurie JD, Zhao W, Tosteson A, Tosteson TD, et al.: Does multilevel lumbar stenosis lead to poorer outcomes?: a subanalysis of the Spine Patient Outcomes Research Trial (SPORT) lumbar stenosis study. Spine (Phila Pa 1976) 35:439446, 2010

48. Postacchini F, Cinotti G: Bone regrowth after surgical decompression for lumbar spinal stenosis. J Bone Joint Surg $\mathrm{Br}$ 74:862869, 1992

49. Radcliff K, Curry P, Hilibrand A, Kepler C, Lurie J, Zhao W, et al.: Risk for adjacent segment and same segment reoperation after surgery for lumbar stenosis: a subgroup analysis of the Spine Patient Outcomes Research Trial (SPORT). Spine (Phila Pa 1976) 38:531-539, 2013

50. Rompe JD, Eysel P, Zollner J, Nafe B, Heine J: Degenerative lumbar spinal stenosis. Long-term results after undercutting decompression compared with decompressive laminectomy alone 
or with instrumented fusion. Neurosurg Rev 22:102-106, 1999

51. Sanderson PL, Getty CJ: Long-term results of partial undercutting facetectomy for lumbar lateral recess stenosis. Spine (Phila Pa 1976) 21:1352-1356, 1996

52. Scholz M, Firsching R, Lanksch WR: Long-term follow up in lumbar spinal stenosis. Spinal Cord 36:200-204, 1998

53. Sinikallio S, Aalto T, Airaksinen O, Herno A, Kroger H, Viinamaki $\mathrm{H}$ : Depressive burden in the preoperative and early recovery phase predicts poorer surgery outcome among lumbar spinal stenosis patients: a one-year prospective follow-up study. Spine (Phila Pa 1976) 34:2573-2578, 2009

54. Slatis P, Malmivaara A, Heliovaara M, Sainio P, Herno A, Kankare J, et al.: Long-term results of surgery for lumbar spinal stenosis: a randomised controlled trial. Eur Spine J 20:1174- 1181, 2011

55. Tsai CH, Chou EC, Chou LW, Chen YJ, Chang CH, Tsou HK, et al.: The evaluation of bladder symptoms in patients with lumbar compression disorders who have undergone decompressive surgery. Spine (Phila Pa 1976) 35:E849-854, 2010

56. Tuite GF, Stern JD, Doran SE, Papadopoulos SM, McGillicuddy JE, Oyedijo DI, et al.: Outcome after laminectomy for lumbar spinal stenosis. Part I: Clinical correlations. J Neurosurg 81:699706, 1994

57. Turner JA, Ersek M, Herron L, Deyo R: Surgery for lumbar spinal stenosis. Attempted meta-analysis of the literature. Spine
(Phila Pa 1976) 17:1-8, 1992

58. Watters WC, 3rd, Baisden J, Gilbert TJ, Kreiner S, Resnick DK, Bono CM, et al.: Degenerative lumbar spinal stenosis: an evidence-based clinical guideline for the diagnosis and treatment of degenerative lumbar spinal stenosis. Spine J 8:305-310, 2008

59. Weinstein JN, Tosteson TD, Lurie JD, Tosteson A, Blood E, Herkowitz H, et al.: Surgical versus nonoperative treatment for lumbar spinal stenosis four-year results of the Spine Patient Outcomes Research Trial. Spine (Phila Pa 1976) 35:1329-1338, 2010

60. Weinstein JN, Tosteson TD, Lurie JD, Tosteson AN, Blood E, Hanscom B, et al.: Surgical versus nonsurgical therapy for lumbar spinal stenosis. N Engl J Med 358:794-810, 2008

61. Xia Y, Ishii K, Matsumoto M, Nakamura M, Toyama Y, Chiba K: Radiographic predictors of residual low back pain after laminectomy for lumbar spinal canal stenosis: minimum 5-year followup. J Spinal Disord Tech 21:153-158, 2008

62. Yamashita K, Ohzono K, Hiroshima K: Five-year outcomes of surgical treatment for degenerative lumbar spinal stenosis: a prospective observational study of symptom severity at standard intervals after surgery. Spine (Phila Pa 1976) 31:1484-1490, 2006

63. Yone K, Sakou T: Usefulness of Posner's definition of spinal instability for selection of surgical treatment for lumbar spinal stenosis. J Spinal Disord 12:40-44, 1999 